method of science but has now become the philosophy of science. Instituted in 1924, it has now some sixty students, and its staff, of which Prof. McKie has been one of the outstanding ornaments, has made a name by careful and scholarly research. In these days as scientific journals increase at the rate of more than a thousand a year, synoptic views need more than ever to be authoritative. Prof. McKie's plea that the history of science should be recognized as a branch of history has already been tried by Dr. J. B. Conant, and University College, London, is trying, too. Looking further, he sees the expansion of this field in the history of technology reaching into the history of medicine. Prof. McKie's modesty makes his inaugural address pleasant reading; one only regrets that it does not include a little autobiography. $\mathrm{He}$, of all men, should be encouraged to tell us of his own writings and work.

\section{Cotton in the Prehistoric Southwestern United States}

THE textiles, old or new, of particular areas have formed the subject of a number of reports published in recent years, which have an interest by no means limited to the areas with which they deal. The late Prof. Lila O'Neale's "Textiles of Highland Guatemala" was a notable example dealing with modern weaving, and a recent report (Trans. Amer. Phil. Soc., N.S., 47, Part 3: The Cultivation and Weaving of Cotton in the Prehistoric Southwestern United States. By Kate Kent. Pp. ii +457-734. 4 dollars), which is concerned mainly with ancient examples, should command an equally wide interest, not only among textile specialists but also among those who are interested in New World archæology. The work has entailed widespread research among museum collections, as well as painstaking study of individual examples, many of them in poor condition. A great deal of this report naturally consists of descriptions of specimens, but the admirable drawings make it easy to follow the processes and to pick out what is of general interest. The bulk of the material available dates from between A.D. 1000 and 1400, but evidence is given for the use of the loom in the area at least as far back as A.D. 700. It may be remarked that it was far older in some other parts of America, and it will be surprising if it does not eventually prove to have reached the south-west of the United States at an earlier date. The account is not limited to loom-woven fabrics, and it includes such processes as twining, besides netting and other single-element techniques. It was found possible to distinguish the products of several sub-areas in the region.

Of particular interest are suggestions as to how and when various processes were introduced from Mexico from a possible ultimate source in Peru. Brief com. parisons are made between looms and processes popular in Peru and the south-west of the United States; twills, for example, are common in the latter and rare in Peru, where warp floats enjoyed a vogue which was lacking farther north. The wide loom, horizontal or vertical, with fixed beams, was largely used alongside the belt loom in the south-west of the United States, whereas the belt loom predominated farther south, and the evidence for the use of a stationary loom in ancient Peru is still unsatisfactory. The Peruvians always had a taste for finger weaves, whereas there was a greater dependence on loom processes in the south-west of the United States. Observations of this sort direct attention to the desirability of a synthetic study of weaving in different parts of ancient America, a work which would be of great interest and value. This report would form one of its foundations.

\section{Silver Jubilee of Polarforschung}

The Archiv für Polarforschung at Kiel has recently published two special issues of its journal, Polar. forschung: one to celebrate the journal's twentyfifth anniversary, and the other in memory of Alfred Wegener. Apart from special emphasis in the second on the German Greenland Expedition of 1930-31, these two issues follow the pattern of their predecessors. There are short articles on a wide variety of subjects ; but scientific results of expeditions are not normally to be found here. The jubilee issue, for example, includes a summary of the weather at Vorkuta by an ex-prisoner there, a discussion of dreams during the polar night by a doctor, a survey of volcanic activity in Iceland since 1700, and many more notes further exemplifying this diversity. The somewhat austere layout and type face, together with the absence of diagrams or illustrations, should not deter the careful reader, who will find information of interest and value not available elsewhere. Polar specialists will be sorry to hear that Dr. Max Grotewahl, the founder and organizer of the Archiv für Polarforschung, died on September 6, shortly after the appearance of these two issues.

\section{National Museum, Bloemfontein}

The annual report of the National Museum at Bloemfontein for the year ended March 31, 1958, (pp. 22. Bloemfontein: National Museum, 1958) records the completion of ten new displays, including dioramas of vultures, pan-life (birds), Uranocentrodon (fossil amphibian) and Aulacocephalodon (fossil reptile). Several minor building extensions have been undertaken, although no start has yet been made on the two new wings for the Museum. Four members of the staff are studying at and writing theses for the Department of Physical Anthropology in the University of the Orange Free State at Bloemfontein, and various grants-in-aid enabled the Museum to undertake large-scale excavations at the Matjes River rock shelter.

\section{Uptake and Translocation of Radioactive Phos- phorus in Plants}

G. N. Thorne (Annals of Botany, N.S., 32, 381 ; 1958) has investigated and discussed the factors which affect the uptake of radioactive phosphorus by leaves and its translocation in the plant. The rate of uptake of phosphorus-32 from solutions of labelled sodium dihydrogen phosphate sprayed on to one leaf of swedes (Brassica napus) or french beans (Phaseolus vulgaris) was rapid during the first few hours and fell to zero after four days. Phosphorus-32 was detected in the root after $3 \mathrm{hr}$. and continued to move out of the treated leaf for at least, six days after application. A larger fraction of the applied phosphorus-32 was absorbed from repeated than from a single spraying. Swedes absorbed more phosphorus -32 from a single application to the lower surface than to the upper surface of the leaf. Doubling the concentration of the spray caused a small increase in the percentage of applied phosphorus-32 that was absorbed. Absorption by french bean leaves decreased slightly when the area sprayed with a constant amount of phosphorus-32 was doubled, and decreased with increasing age of leaf. Increasing the supply of phosphorus to the roots of 